\title{
Connective tissue metabolism in chikungunya patients
} Sudarsanareddy Lokireddy ${ }^{1}$, Sarojamma Vemula ${ }^{2}$ and Ramakrishna Vadde*1

Address: ${ }^{1}$ Department of Biotechnology, Sri Krishnadevaraya University, Anantapur, India and ${ }^{2}$ Department of Community Medicine, Government Medical College, Anantapur, India

Email: Sudarsanareddy Lokireddy - l_suda2003@yahoo.co.in; Sarojamma Vemula - vemula_saroja@yahoo.co.in; Ramakrishna Vadde* - krishnavr2007@rediffmail.com

* Corresponding author

Published: 27 February 2008

Virology Journal 2008, 5:31 doi:10.1186/|743-422X-5-31

This article is available from: http://www.virologyj.com/content/5/I/3।

(c) 2008 Lokireddy et al; licensee BioMed Central Ltd.

This is an Open Access article distributed under the terms of the Creative Commons Attribution License (http://creativecommons.org/licenses/by/2.0), which permits unrestricted use, distribution, and reproduction in any medium, provided the original work is properly cited.
Received: 16 January 2008

Accepted: 27 February 2008

\begin{abstract}
Background: Chikungunya (CHIK) fever is a viral disease transmitted to humans by the bite of Chikungunya virus (CHIK virus) infected Aedes mosquitoes. CHIK virus is a member of the Alphavirus genus of the family Togaviridae. Previous reports have indicated that infection with $\mathrm{CHIK}$ virus produces an acute arthritis in human hosts by large area of necrosis and collagenosis or fibrosis.

Results: We carried out the present study to determine the effect of chikungunya on the collagen and connective tissue metabolism in 75 chikungunya-affected people. First, we screened for mucopolysaccharides in urine by Cetyl Trimethyl Ammonium Bromide (CTAB) test. Appearance of heavy precipitate indicates the presence of higher levels of mucopolysaccharides and later quantified by DMB dye method. The urinary mucopolysaccharide in CHIK patients was $342 \pm 45$ $\mathrm{mg} / \mathrm{l}$ compared to healthy controls $(45 \pm 5.6 \mathrm{mg} / \mathrm{l})$. The collagen building blocks, proline and hydroxyproline were also measured in $\mathrm{CHIK}$ patients and observed higher excretion compared to healthy controls. Urinary excretions hydroxyproline was greater than the proline levels.

Conclusion: These results indicate that CHIK virus infection affects and damage the cartilage and connective metabolism and releases the degraded products from the tissue and responsible for increasing the levels of proline, hydroxyproline and mucopolysaccharides in CHIK affected patients.
\end{abstract}

\section{Background}

Chikungunya (CHIK) fever is a viral disease transmitted to humans by the bite of Chikungunya virus (CHIK virus) infected Aedes mosquitoes. CHIK virus is a member of the Alphavirus genus of the family Togaviridae. CHIK virus was first isolated from the serum of a febrile patient during a dengue epidemic that occurred in the Newala District, Tanzania in 1953 [1]. The Alphaviruses are enveloped particles and their genome consists of a single-stranded, positive-sense RNA molecule of approximately 12000 nucleotides. CHIK virus is an important human pathogen that causes a disease syndrome characterized by fever, headache, rash, nausea, vomiting, myalgia and arthralgia [2-8]. Its association with a fatal haemorrhagic condition was reported in India [9]. CHIK virus is geographically distributed from Africa through Southeast Asia, and its transmission to humans is mainly through Aedes species mosquitoes [1]. Since 1953, CHIK viurs has caused numerous well-documented outbreaks and epidemics in both Africa and Southeast Asia, involving hundreds of thousands of people [10-12]. Recent reports have described a massive outbreak of CHIK disease occurring 
on islands in the Indian Ocean, off the east coast of Africa $[5,8,13]$. Reemergence of CHIK has also been reported from Indonesia [14] and very recent massive outbreak in India. No treatment or vaccine is available, and relatively little research has been conducted into its pathogenesis, compared with that of other Arboviruses, such as dengue.

Previous reports have indicated that infection with CHIK virus produces an acute arthritis in human hosts $[7,15,16]$ by large area of necrosis and collagenosis or fibrosis [17]. Arthritis is the inflammation of a joint and its surrounding tissues, including the cartilage, ligaments, and tendons. Connective tissue is mainly composed of mucopolysaccharides, protein substances - collagen with major amino acids proline, hydroxyproline etc, calcium, sulfur, and collagen. Mucopolysaccharide, proline and hydroxyproline measurements in urine are used in the diagnosis and treatment of various inheritable disorders that affect bone and connective tissues. Their presence in urine is originated from ground substance of collagen, and bone [18-20]. Though many reports state that CHIK virus produces arthritis in humans. The biochemical mechanisms and the changes of mucopolysaccharides, proline and hydroxyproline in this acute joint pain have not been reported in past literature. During last year monsoon outbreak of CHIK fever in Southern parts of India has led us to carryout the experiments on the effect of CHIK virus on the collagen and connective tissue. In this study we collected the blood and urine samples from chronic CHIK fever patients and studied biochemical parameters related to connective tissue, which is responsible for acute joint pains and arthritis.

\section{Results}

CHIK patients have reported incapacitating joint pain, or arthritis, which may last for weeks or months. The general biochemical parameters of CHIK patients and healthy controls were depicted in Table 1 . Serum albumin and creatinine were showing significant variation with controls.

Table I: Biochemical characteristics of normal and Chikungunya patients

\begin{tabular}{cccc}
\hline S. No & Clinical data & Normal & Chikungunya \\
\hline I. & Number & 20 & 75 \\
& & $\mathrm{~F}-6, \mathrm{M}-\mathrm{I}$ & $\mathrm{F}-30, \mathrm{M}-45$ \\
2. & Age (years) & $20-50$ & $15-60$ \\
3. & Blood glucose & $80 \pm 12 \mathrm{mg} / \mathrm{dl}$ & $90 \pm 16 \mathrm{mg} / \mathrm{dl}$ \\
4. & Serum total protein & $7.15 \pm 0.96 \mathrm{~g} / \mathrm{dl}$ & $6.96 \pm 0.6 \mathrm{~g} / \mathrm{dl}$ \\
5. & Serum albumin & $4.04 \pm 0.45 \mathrm{~g} / \mathrm{dl}$ & $3.60 \pm 0.24 \mathrm{~g} / \mathrm{dl} \$$ \\
6. & A:G ratio & $\mathrm{I}-2$ & $0.96 \pm 0.4$ \\
7. & Blood urea & $36 \pm 8 \mathrm{mg} / \mathrm{dl}$ & $41 \pm 10 \mathrm{mg} / \mathrm{dl}$ \\
8. & Serum creatinine & $0.96 \pm 0.23 \mathrm{mg} / \mathrm{dl}$ & $1.22 \pm 0.12 \mathrm{mg} / \mathrm{d} \mid \$$
\end{tabular}

F-Female, M-Male, mg- milli gram, dl- deci litre.

Results are expressed as mean \pm SD. ${ }^{\$} p<0.05$ against the control values
We carried out the present study to determine the effect of CHIK on collagen and connective tissue metabolism by measuring the levels of mucopolysaccharide, hydroxyproline and proline in urine samples of CHIK patients. Urine from 75 different patients suffering with CHIK was evaluated for the presence of mucopolysaccharides by screening cetyl trimethyl ammonium bromide (CTAB) test in urine. Appearance of heavy precipitate indicates the presence of mucopolysaccharides in the sample. The amount of precipitate depends on the concentration of mucopolysaccharides. Depending upon their concentration, samples were classified as negative, mild, moderate, and severe. In this study, we observed moderate to severe cases. The healthy controls showed no precipitate with $\mathrm{CTAB}$. We also measured quantitatively urinary mucopolysaccharides levels in the first morning urine specimens by the simple and rapid DMB method and used in understanding the pathophysiology of arthritis in CHIK diseases. Urinary mucopolysaccharides (GAG) excretion in patients increased significantly compared to healthy controls. We also observed the significant variation in the levels of urinary excretions of hydroxyproline and proline with healthy controls (Table 2). The patients suffering with CHIK excreted higher levels of hydroxylproline than proline. We also carried out the follow up study for 10 patients with their consent up to one week who has chronic arthritic pains. The urinary excreted mucopolysaccharides are continuously high in the first two days and the levels were slowly decreasing on later days, but at the end of one week (up to 10 days) we found still the patients are excreting higher values compare to control (Table 3). The changes in the levels of urinary hydroxyproline and proline were also measured and observed the significant difference with healthy controls.

\section{Discussion}

Proteoglycan, a mucopolysaccharide building block of cartilage within the joint space, is used by chondrocytes (cartilage-building cells) to create more cartilage. Following pathogenic infection, joints typically exhibit a natural inflammatory response that mainly affects the synovium (synovitis). This process is necessary for the innate repair of damaged tissues, allowing the joint to recoup normal function. Inflammatory mediators released into the joint from such sources as nerves, immunocytes, synoviocytes,

Table 2: Effect of chikungunya (on average day 3-5) on the levels of proline, hydroxyproline and acid mucopolysaccharides

\begin{tabular}{cccc}
\hline SI No. & Parameter & Control & Chikungunya \\
\hline I. & Proline & $1.4 \pm 0.18 \mathrm{mg} / \mathrm{l}$ & $22 \pm 3.2 \mathrm{mg} / \mathrm{I}^{\$}$ \\
2. & Hydroxyproline & $25 \pm 1.8 \mathrm{mg} / \mathrm{l}$ & $210 \pm 34 \mathrm{mg} / \$$ \\
3. & Mucopolysaccharides & $45 \pm 5.8 \mathrm{mg} / \mathrm{l}$ & $342 \pm 45 \mathrm{mg} / \$$ \\
\hline
\end{tabular}

Results are expressed as mean \pm SD. ${ }^{\$} p<0.05$ against the control values 
Table 3: Changes of urinary proline, hydroxyproline and mucopolysaccharides during week long Chikungunya fever.

\begin{tabular}{cccc}
\hline Day & Proline $\mathbf{~ m g / l}$ & Hydroxyproline $\mathbf{~ m g / l}$ & Mucopolysaccharides mg/l \\
\hline Day I & $32 \pm 2.1$ & $263 \pm 22$ & $380 \pm 45$ \\
Day 2 & $30 \pm 1.6$ & $251 \pm 43$ & $372 \pm 30$ \\
Day 3 & $25 \pm 2.0$ & $228 \pm 38$ & $354 \pm 26$ \\
Day 4 & $20 \pm 1.8$ & $210 \pm 24$ & $325 \pm 28$ \\
Day 5 & $16 \pm 2.0$ & $186 \pm 15$ & $300 \pm 30$ \\
Day 6 & $15 \pm 1.5$ & $160 \pm 13$ & $260 \pm 22$ \\
Day 7 & $10 \pm 0.8$ & $138 \pm 11$ & $2210 \pm 18$ \\
Day 8 & $10 \pm 0.5$ & $130 \pm 10$ & $185 \pm 10$ \\
Day 9 & $9 \pm 0.8$ & $120 \pm 14$ & $160 \pm 12$ \\
Day 10 & $7 \pm 0.54$ & $100 \pm 10$ & 10 \\
\hline
\end{tabular}

and vascular endothelium help to orchestrate these healing responses. These same inflammatory mediators also act on joint sensory nerves, leading to either excitation or sensitization [21]. When people suffer from arthritis, they experience a selective destruction of collagen within the cartilage of their joints. Collagen is the most abundant structural protein in cartilage. It helps provide elasticity of joints and works as the "glue" that holds together the various components of cartilage. It also contains the majority of mucopolysaccharides that give cartilage its healing powers. Mucopolysaccharides are large-molecular mass linear carbohydrate polymers composed of glucuronic or iduronic acid and $\mathrm{N}$-acetylglycosamine or $\mathrm{N}$-acetylgalactosamine units. Chondroitin sulfate and heparan sulfate are derived from proteoglycans in which these glycosaminoglycans (GAG) are covalently linked at the reducing end to the hydroxyl group of serine residues [22]. Proteoglycans containing GAG bound to hyaluronic acid form large aggregates that are enmeshed in a collagen network as the principal structural constituents of cartilage. Loss of proteoglycans is an early feature of matrix resorption. The erosion of the cartilage lining the joints is a hallmark of osteoarthritis. A corresponding increase in GAGs has been reported in synovial fluid, serum, and urine of patients with rheumatic arthritic diseases $[23,24]$. Consistent with this, we observed in our studies higher excretion of mucopolysaccharides through urine (Table 2).

Measurement of urinary hydroxyproline excretion is used to estimate collagen catabolism. Degradation of bone collagen releases free 4-hydroxyproline and peptides containing 4-hydroxyproline into the plasma. Urinary hydroxyproline measurement is particularly useful in monitoring treatment and progress in metabolic bone diseases such as osteomalacia and osteoporosis and Paget's disease. Hydroxyprolme appears in urine after degradation of collagen (collagenosis), which may originate from various tissues [25]. Measuring urinary hydroxyproline has predominantly been used to indicate bone collagen turnover in normal and pathological conditions. Colla- gen, which constitutes $>90 \%$ of the fat-free organic matrix of bone, is important in its structural integrity and is the central element of connective tissue structure in which the mineral phase crystallizes during bone formation $[20,26]$. Urinary hydroxyproline reflects daily collagen turnover and in humans has shown great potential as an index of nutritional status and growth rate $[27,28]$. The CHIK patients showed higher excreted levels of hydroxyproline than proline indicates increased collagen turnover (Table 2). On follow-up study in the selected CHIK patients, increased levels of mucopolysacchariedes, proline and hydroxyproline indicates highermetabolic turnover in early days and recedes progressively in later days (Table $3)$.

\section{Conclusion}

In CHIK patients the collagen and connective tissue metabolism was greatly affected and increased metabolism leads to increased excretion of proline, hydroxyproline and mucopolysaccharides in urine compared to healthy controls. It indicates that the CHIK virus infection, connective tissue typically exhibits inflammatory response and leads to the damage of cartilage and connective tissue; increases metabolism and releases degraded products in to blood and ultimately excreted through urine.

\section{Materials and methods Subjects}

During last year July - October 2006, CHIK out break in Andhra Pradesh, India, a total of 75 (45 males +30 females) patients were selected based on disease symptoms for this study. We also taken the 20 age-matched healthy persons were chosen from the community and used as control subjects. Blood and urine samples were collected from each subject with their prior written consent for further studies. From all subjects, $5 \mathrm{ml}$ of blood was collected in heparinized tubes and centrifuged at $1500 \times \mathrm{g}$ for $15 \mathrm{~min}$ at $4 \mathrm{C}$. Plasma and pelleted RBC were separated stored in eppendorf tubes and kept at $-80 \mathrm{C}$ 
until analysis. Commercially available kits measured Blood analysis and other general parameters.

\section{Urine analysis}

The urine samples were collected from the patients and used for estimation of mucopolysaccharides, proline and hydroxyproline. Total urinary hydroxyproline determinations were performed employing the method described by Cleary and Saunders (1974) [29]. Briefly, urine was passed through a column of ion retardation resin to remove acid, salts, and pigments. From the column eluate, urine hydroxyproline determination was performed by oxidized to pyrrole 2-carboxylic acid and then to pyrole. The color produced with dimethyl amino-benzaldehyde is masured at $560 \mathrm{~nm} \mathrm{[30].} \mathrm{The} \mathrm{proline} \mathrm{levels} \mathrm{in} \mathrm{urine}$ sample were measured by the method of Bates et al (1973) [31]. Two $\mathrm{ml}$ urine sample mixed with $2 \mathrm{ml}$ acid ninhydrin reagent and kept in boiling water bath for $1 \mathrm{~h}$. The tubes transferred to an ice bath to terminate the reaction. $5 \mathrm{ml}$ toluene was added and mixed and read at 520 $\mathrm{nm}$ against the toluene blank. Screening test for mucopolysaccharides in urine was tested by Cetyl Trimethyl Ammonium Bromide (CTAB) test. Five $\mathrm{ml}$ of fresh urine was added to $1 \mathrm{ml}$ of CTAB (cetavilon) solution $(50 \mathrm{~g} / \mathrm{l}$ in citrate buffer $(1 \mathrm{M})$ of $\mathrm{pH} 6.0)$. A heavy precipitate indicated the presence of mucopolysaccharides (Varley et al 1990). The DMB assay was performed essentially for measurement of mucopolysaccharides according to the method of Whitley et al. (1989) [32]. Briefly, the DMB (1,9-dimethylmethylene blue) dye solution was prepared by dissolving $16 \mathrm{mg}$ of $\mathrm{DMB}, 3.04 \mathrm{~g}$ of glycine, $2.37 \mathrm{~g}$ of sodium chloride, and $0.5 \mathrm{~mL}$ of $0.1 \mathrm{~mol} / \mathrm{l}$ hydrochloric acid in $1 \mathrm{l}$ of distilled water. The $\mathrm{pH}$ of the solution was adjusted to 3. For each assay, the patient's urine specimen was mixed with $1 \mathrm{ml}$ of the dye solution at room temperature, and measured absorbance at $525 \mathrm{~nm}$ without delay after mixing the sample and dye solution. The assay was calibrated verses a standard curve of chondroitin sulfate $(5-100 \mathrm{mg} / \mathrm{l})$. The results were expressed as $\mathrm{mg} / \mathrm{l}$. All colorimetric estimations of above biochemical parameters in samples were measured by using BIOTEK ELISA Reader.

\section{Statistical analysis}

Statistical analysis was performed by GraphPad InStat software. Subjects with CHIK were compared with healthy controls. Means and standard error of means were calculated and differences between means were student's t-test.

\section{Authors' contributions}

SL designed and conducted the experiments with patient's blood, urine samples. SL also performed the final statistical analysis of the data and contributed to writing the paper. SV (she is specialist in infectious diseases) guide to us for selecting the chikungunya patients for research dur- ing time of blood and urine collection. RV supervised the overall project, designed experiments, analyzed the data and wrote the paper. All authors read and approved the final manuscript.

\section{Acknowledgements}

The publication was conducted as part of the programme 'Biotechnology for Dry land Agriculture in Andhra Pradesh' with financial support for the Research and Communication Division, Ministry of Foreign Affairs, the government of Netherlands. Andhra Pradesh Netherlands Biotechnology Programme, IPE, Hyderabad, India.

\section{References}

I. Ross RW: The Newala epidemic. III. The virus: isolation, pathogenic properties and relationship to the epidemic. Journal of Hygiene 1956, 54:|77-9|.

2. Thaikruea L, Charearnsook $O$, Reanphumkarnkit S, Dissomboon $P$, Phonjan R, Ratchbud S, et al: Chikungunya in Thailand: a reemerging disease? Southeast Asian J Trop Med Public Health 1997, 28:359-64.

3. Diallo M, Thonnon J, Traore-Lamizana M, Fontenille D: Vectors of Chikungunya virus in Senegal: current data and transmission cycles. American Journal of Tropical Medicine and Hygiene 1999, 60:281-286.

4. Powers AM, Brault Aaron C, Tesh Robert B, Weaver Scott C: Reemergence of chikungunya and o'nyong-nyong viruses: evidence for distinct geographical lineages and distant evolutionary relationships. Journal of General Virology 2000, 8 I:47 I-479.

5. Schuffenecker I, Iteman I, Michault A, Murri S, Frangeul L, Vaney MC, et al.: Genome microevolution of chikungunya viruses causing the Indian Ocean outbreak. PLOS Med 2006, 6:263.

6. NICD. National Institute of Communicable Disease, New Delhi: Chikungunya Fever. CD Alert 2006, I0(2):6-8.

7. Paquet C, Quatresous I, Solet JL, Sissoko D, Renault P, Pierre V, Cordel H, Lasalle C, Thiria J, Zeller H, Schuffnecker I: Chikungunya outbreak in Reunion: Epidemiology and surveillance. Euro Surveill 2006, I I:2.

8. Nelson Lee, Wong Chun K, Lam Wai Y, Wong Ann, Lim Wilina, Lam Christopher WK, Cockram Clive S, Sung Joseph JY, Chan Paul KS, Tang Julian W: Chikungunya fever, Hong Kong. Emerging Infectious Diseases 2006, I 2:1790.

9. Sarkar JK, Chatterjee SN, Chakravarty SK: Haemorrhagic fever in Calcutta: some epidemiological observations. Indian J Med Res 1964, 52(7):65I-9.

10. Rao TR: Recent epidemics caused by Chikungunya virus in India, 1963 - 1965. Scientifc Culture 1966, 32:215.

II. Halstead SB, Scanlon JE, Umpaivit P, Udomsakdi S: Dengue and Chikungunya virus infection in man in Thailand, $1962 \pm 1964$. IV. Epidemiologic studies in the Bangkok metropolitan area. American Journal of Tropical Medicine and Hygiene 1969, I 8:997-1021.

12. Posey D, O'Rourke Thomas, Roehrig John $t$, Lanciotti Robert $s$, Weinberg Michelle, Maloney Susan: Short report: o'nyong-nyong fever in West Africa. Am J Trop Med Hyg 2005, 73(I):32.

13. Lahariya C, Pradhan SK: Emergence of chikungunya virus in Indian subcontinent after 32 years: a review. J Vect Borne Dis 2006, 43: I5I-160.

14. Laras K, Sukri NC, Larasati RP, Bangs MJ, Kosim R, Djauzi WT, et al.: Tracking the re-emergence of epidemic chikungunya virus in Indonesia. Trans R Soc Trop Med Hyg 2005, 99: 128.

15. Kennedy Ac, Flemming J, Solomon L: Chikungunya viral arthropathy: a clinical description. J Rheumatol 1980, 7:231-6.

16. Fourie ED, Morrison JG: Rheumatoid arthritic syndrome after chikungunya fever. S Afr Med J 1979, 56:130-2.

17. Ozden S, Huerre M, Riviere J-P, Coffey LL, Afonso PV, et al.: Human Muscle Satellite Cells as Targets of Chikungunya Virus Infection. PLOS ONE 2007, 2(6):527.

18. Dull TA, Henneman PH: Urinary hydroxyproline as an index of collagen turnover in bone. New Engl J Med 1963, 268:I32.

19. Kawata H, Koizumi T, Wada R, Yo-Shida T: Urinary acid mucopolysaccharide excretion in liver damage. Gastroenterology 1959, 40:507. 
20. Grant C, Kachniar JF: Amino acids and related metabolites. In Fundamentals of clinical chemistry. In Philadelphia, Pennsylvania Edited by: Tietz NW. WB Saunders Co; 1982:377-400.

21. Dougall Jason JMc: Arthritis and pain: Neurogenic origin of joint pain. Arthritis Research \& Therapy 2006, 8:220.

22. Margolis RK, Margolis RU: Structure and localization of glycoproteins and glycosaminoglycans. In Neurobiology of glycoconjugates Edited by: Margolis RU, Margolis RK. New York: Plenum; 1989:85-126.

23. Bensouyad A, Hollander AP, Dularay B, et al:: Concentrations of glycosaminoglycans in synovial fluids and their relation with immunological and inflammatory mediators in rheumatoid arthritis. Ann Rheum Dis 1990, 49:30I-7.

24. Vladimir Kery, Orlovska Maria, Stanlkova Maria, Risko Martin, Zlna Daniel: Urinary Glycosaminoglycan Excretion in Rheumatic Diseases. Clinical chemistry 1992, 38(6):84I.

25. Dequeker J, Mbuyi-Muamba JM, Holvoet G: Hydroxyproline and bone metastasis. In Bone metastasis: monitoring and treatment Edited by: Stoll BA, Parbhoo S. New York: Raven Press; 1983:181-99.

26. Smith $R$, Elia $M$ : The significance of urinary hydroxyproline and 3-methylhistidine changes in growth, starvation and injury. In Amino-acid analysis Edited by: Rattenbury JM. New York: Haistead Press; 1981:225-36.

27. Whitehead RC: Hydroxyproline creatinine ratio as an index of nutritional status and rate of growth. Lancet 1965:567-570.

28. Howells CR, Wharton BA, Mc Cane RA: Value of hydroxyproline indices in malnutrition. Lancet 1967:1082-1083.

29. Cleary I, Saunders PA: A simplified procedure for the measurement of total hydroxyproline in urine. Clin Chem Acta 1984, 57:217-223.

30. Raghuramulu N, Madhavan Nair K, Kalyanasundaram S: A manual of laboratory techniques. NIN 2003.

31. Bates LS, Waldron RP, Teare EP: Rapid determination of free proline for stress status. Plant and Soil 1973, 39:205-208.

32. Whitley CB, Rindour MD, Draper KA, Dutton CM, Neglia JP: Diagnostic test for mucopolysaccharidosis. I. Direct method for quantifying excessive urinary glycosaminoglycan excretion. Clin Chem 1989, 35:374-9.

Publish with BioMed Central and every scientist can read your work free of charge

"BioMed Central will be the most significant development for disseminating the results of biomedical research in our lifetime. "

Sir Paul Nurse, Cancer Research UK

Your research papers will be:

- available free of charge to the entire biomedical community

- peer reviewed and published immediately upon acceptance

- cited in PubMed and archived on PubMed Central

- yours - you keep the copyright 